\title{
Polymorphisms within inflammatory genes and colorectal cancer
} Stefano Landi ${ }^{* 1,8,9}$, Federica Gemignani ${ }^{1}$, Fabio Bottari ${ }^{1}$, Lydie GioiaPatricola $^{2}$, Elisabet Guino ${ }^{3}$, María Cambray ${ }^{3}$, Sebastiano Biondo ${ }^{4,6}$, Gabriel Capella ${ }^{3}$, Laura Boldrini ${ }^{5,7}$, Federico Canzian ${ }^{8}$ and Victor Moreno ${ }^{3,4,6}$

Address: ${ }^{1}$ Genetics-Department of Biology, University of Pisa, via S. Giuseppe 22, 56126, Pisa, Italy, ${ }^{2}$ International Agency for Research on Cancer, 150 Cours Albert Thomas, 69372 Lyon, France, ${ }^{3}$ Institut Catala d'Oncologia, Hospitalet, Barcelona, Spain, ${ }^{4}$ Laboratori d'Estadistica i Epidemiologia, Facultat de Medicina, Universitat Autonoma de Barcelona, Barcelona, Spain, ${ }^{5}$ Department of Surgery, AOUP, via Roma 57, 56126, Pisa, Italy, ${ }^{6}$ Unidad de Cirugía Colorrectal, Hospital Universitario de Bellvitge, Hospitalet, Barcelona, Spain, ${ }^{7}$ Department of Chirurgic, Area Vasta Nord-Ovest (Toscana), S. Chiara Hospital, Pisa, Italy, ${ }^{8}$ Genomic Epidemiology Group, German Cancer Research Center (DKFZ), Im NeuenheimerFeld 580, D-69120 Heidelberg, Germany and 'IDIBELL, Hospital Universitari de Bellvitge, Hospitalet, Barcelona, Spain

Email: Stefano Landi* - slandi@biologia.unipi.it; Federica Gemignani - fgemignani@biologia.unipi.it; Fabio Bottari - bottarifabio@gmail.com; Lydie Gioia-Patricola - gioia@iarc.fr; Elisabet Guino - e.guino@iconcologia.net; María Cambray - mcambray@iconcologia.net; Sebastiano Biondo - sbiondo@csub.scs.es; Gabriel Capella - gcapella@iconcologia.net; Laura Boldrini - l.boldrini@med.unipi.it; Federico Canzian - f.canzian@dkfz.de; Victor Moreno - v.moreno@iconcologia.net

* Corresponding author

Published: 24 October 2006

Journal of Negative Results in BioMedicine 2006, 5:15 doi:10.1 186/1477-575I-5-15

This article is available from: http://www.jnrbm.com/content/5/I/l5

(C) 2006 Landi et al; licensee BioMed Central Ltd.

This is an Open Access article distributed under the terms of the Creative Commons Attribution License (http://creativecommons.org/licenses/by/2.0), which permits unrestricted use, distribution, and reproduction in any medium, provided the original work is properly cited.
Received: 09 June 2006

Accepted: 24 October 2006

\begin{abstract}
Background: Chronic inflammation is a risk factor for colorectal cancer and polymorphisms in the inflammatory genes could modulate the levels of inflammation. We have investigated ten single nucleotide polymorphisms (SNPs) in the following inflammation-related genes: TLR4 (Asp299Gly), CD I 4 (-260 T>C), MCPI (-25I8 A>G), ILI2A (+7506 A>T, +8707 A>G, +9I77 T>A, +9508 G>A), NOS2A (+524T>C), TNF (-857C>T), and PTGSI (V444I) in 377 colorectal (CRC) cancer cases and 326 controls from Barcelona (Spain).

Results: There was no statistically significant association between the SNPs investigated and colorectal cancer risk.

Conclusion: The lack of association may show that the inflammatory genes selected for this study are not involved in the carcinogenic process of colorectum. Alternatively, the negative results may derive from no particular biological effect of the analysed polymorphisms in relation to CRC. Otherwise, the eventual biological effect is so little to go undetected, unless analysing a much larger sample size.
\end{abstract}

\section{Background}

Epidemiological and biological data show a clear association between chronic inflammatory conditions and subsequent malignant transformation in the inflamed tissue [1]. Inflammatory state is typically accompanied by generation of free radicals, stimulation of cytokines, chemokines, and growth and angiogenic factors that favor tumorigenesis by damaging DNA [2,3], stimulating angiogenesis [4], and by inducing cell proliferation $[5,6]$. Following these considerations, some pro-inflammatory genes have been shown to be important for the maintenance and progression of cancer [7], including colorectal cancer (CRC) $[8,9]$. 
Toll-like and CD14 receptors are examples of pattern recognition receptors that detect antigenic molecules on the surface of gram-positive (peptidoglycans, lipoteichoic acid) and gram-negative (lipopolysaccharide, LPS) bacteria [10]. Polymorphisms of TLR4 gene appear to be able to alter inflammatory responses in numerous experimental and clinical models of inflammation. Asp299Gly polymorphism [dbSNP: rs4986790] within TLR4 has been investigated by several groups and associated with an increased response to LPS [11]. CD14 is a gene preferentially expressed on monocytes/macrophages generating a surface protein. It binds lipopolysaccharide-binding protein and recently has been shown to bind apoptotic cells [10]. The polymorphism -260 T>C [dbSNP: rs2569190] has been shown to increase transcriptional activity by lowering the affinity of the GC box for Sp3, a factor known to inhibit the activity of a number of promoters. This enhanced transcriptional activity has been associated with higher concentrations of soluble CD14 and enhanced CD14 expression on the membrane of the monocytes [12].

MCP-1 is a chemokine that is thought to be responsible for monocyte and T-lymphocytes recruitment in acute inflammatory conditions and may be an important mediator in chronic inflammation. The $\mathrm{G}$ allele of $-2518 \mathrm{~A}>\mathrm{G}$ MCP1 polymorphism [dbSNP: rs1024611] was found to increase MCP-1 expression [13].

IL12A encodes a subunit (alpha) of a cytokine that is required for the T-cell-independent induction of interferon (IFN)-gamma. IL-12 was believed to be unique in its ability to induce the differentiation of native $\mathrm{T}$ cells toward the TH1 phenotype and in its pathogenic activity, as shown in various disease models including inflammatory bowel disease (IBD) [14]. SNPs in the regulatory sequence of IL12A are presumed to be associated with the differential production of this cytokine [15].

Focusing on pathways involved more specifically in chronic inflammatory bowel disorders and CRC, the nitric oxide (NO) is a versatile molecule with actions ranging from haemodynamic regulation to anti-proliferative effects on vascular smooth muscle cells [16]. NO is produced by the nitric oxide synthases, endothelial NOS (eNOS), neural NOS (nNOS), and inducible NOS (iNOS). NOS2A is the encoding gene for the inducible NOS. It is required for the signalling process in the innate immunity [17] and it plays a central role on chronic inflammatory bowel disorders [18].

Tumor necrosis factor (TNF; formerly known as TNF $\alpha$ ) and lymphotoxin- $\alpha$ (LTA), originally characterized by their ability to induce tumor cell apoptosis and cachexia, are now considered as central mediators of a broad range of biological activities (for a review see [19] and [20]). These activities encompass beneficial effects for the host in inflammation and in protective immune responses against a variety of infectious pathogens [21]. In addition, it has been demonstrated that the core members of the TNF superfamily, including LT $\alpha$, play an essential role during the organogenesis of secondary lymphoid organs and the maintenance of the architecture of lymphatic tissues [21]. Although a large study did not show association between polymorphisms within LTA-TNF region on chromosome 6 and IBD [22], the role of LTA in the etiology of IBD has been well ascertained in mice [23].

Several lines of evidence suggest that cyclo-oxygenases (COX) 1 and 2 enzymes, encoded by PTGS1 and PTGS2 genes, play a significant role in colon carcinogenesis. For example, rapid metabolism of arachidonic acid and elevated levels of COX enzymes are found in several cancers, including CRC [24]. In addition, COX enzymes have been shown to stimulate cell proliferation, angiogenesis, and metastasis, and to inhibit apoptosis [25]. During the inflammatory state COX enzymes are elevated, thus the regular use of non-steroidal anti-inflammatory drugs (NSAIDs) could be associated with a reduced risk of CRC, through their inhibition [26]. While COX-2 is rapidly inducible and its expression is usually elevated at sites of inflammation, COX-1 is considered constitutive and is thought to be the main responsible for the cytoprotective production of prostaglandins. However, the traditional description of COX-1 as a purely constitutive, housekeeping gene has been recently challenged by several studies, which have found that COX-1 production can also be regulated at the transcriptional level [27].

In previous investigations, we performed a case-control association study on several polymorphisms in genes involved in the inflammation (namely: ILG, IL8, PPARG, TNF, NFKB1 and PTGS2) and we found associations with the risk of sporadic colorectal cancer $[9,28]$. In the present study, in order to evaluate whether single nucleotide polymorphisms (SNPs) within more inflammatory genes were associated with the risk to develop CRC, we investigate ten SNPs in the following inflammatory genes: TLR4 (Asp299Gly), CD14 (-260 T>C), MCP1 (-2518 A>G), IL12A (+7506 A>T, +8707 A>G, +9177 T>A, +9508 G>A), NOS2A $(+524 \mathrm{~T}>\mathrm{C}), T N F(-857 \mathrm{C}>\mathrm{T})$, and PTGS1 (V444I) in 377 cases and 326 controls.

\section{Results and Discussion}

Each polymorphism was in Hardy-Weinberg equilibrium in controls. The main effects related to each polymorphism by case/control status are shown in Table 1 . The odd ratios (ORs) and 95\% confidence interval (CI) are shown for the codominant model. For the variant V444I within PTGS1, we found an allele frequency too low to 
Table I: Odd ratios and $95 \%$ confidence intervals $(95 \% \mathrm{Cl})$ for colorectal cancer by genotypes under investigation.

\begin{tabular}{|c|c|c|c|c|c|}
\hline Gene and SNP & Controls $\mathbf{N}^{\circ}$ & Cases $\mathbf{N}^{\circ}$ & OR $(95 \% \mathrm{Cl})$ & $P_{\text {codominant }}{ }^{\prime}$ & $P_{\text {additive }}{ }^{2}$ \\
\hline \multicolumn{6}{|l|}{ TLR4 Asp299Gly } \\
\hline AA & 232 & 251 & I & & \\
\hline$A G$ & 37 & 31 & $0.75(0.45-1.27)$ & 0.29 & 0.29 \\
\hline GG & 0 & 0 & N.A. & & \\
\hline \multicolumn{6}{|l|}{$C D / 4-260 T>C$} \\
\hline TT & 63 & 68 & 1 & & \\
\hline TC & 137 & $|5|$ & $0.98(0.65-1.50)$ & 0.82 & 0.58 \\
\hline CC & 65 & 62 & $0.87(0.53-1.43)$ & & \\
\hline \multicolumn{6}{|l|}{$M C P I-25 / 8 A>G$} \\
\hline AA & 138 & 161 & 1 & & \\
\hline AG & 97 & 97 & $0.86(0.6-1.24)$ & 0.71 & 0.46 \\
\hline GG & 16 & 18 & $0.88(0.43-1.82)$ & & \\
\hline \multicolumn{6}{|l|}{$I L I 2 A+7506 A>T$} \\
\hline $\mathrm{AA}$ & 97 & 102 & I & & \\
\hline AT & 108 & 136 & $1.19(0.81-1.74)$ & 0.49 & 0.99 \\
\hline $\mathrm{TT}$ & 41 & 37 & $0.90(0.53-1.53)$ & & \\
\hline \multicolumn{6}{|l|}{ ILI $2 A+8707 A>G$} \\
\hline AA & 75 & 69 & I & & \\
\hline AG & 121 & 149 & $1.30(0.86-1.96)$ & 0.25 & 0.87 \\
\hline GG & 68 & 59 & $0.94(0.58-1.53)$ & & \\
\hline \multicolumn{6}{|l|}{$I L I 2 A+9 \mid 77 T>A$} \\
\hline TT & 100 & 108 & I & & \\
\hline TA & $12 \mid$ & 140 & $\mid .04(0.72-|.5|)$ & 0.73 & 0.68 \\
\hline $\mathrm{AA}$ & 43 & 39 & $0.85(0.5 \mathrm{I}-1.43)$ & & \\
\hline \multicolumn{6}{|l|}{ ILI $2 A+9508 G>A$} \\
\hline GG & 104 & 106 & 1 & & \\
\hline GA & 124 & 135 & $1.05(0.73-\mid .52)$ & 0.85 & 0.85 \\
\hline $\mathrm{AA}$ & 40 & 36 & $0.91(0.53-1.54)$ & & \\
\hline \multicolumn{6}{|l|}{$N O S 2 A+524 T>C$} \\
\hline $\mathrm{TT}$ & 93 & 92 & 1 & & \\
\hline CT & 127 & 142 & $1.15(0.79-1.68)$ & 0.76 & 0.56 \\
\hline $\mathrm{CC}$ & 45 & 49 & $1.12(0.68-1.86)$ & & \\
\hline \multicolumn{6}{|l|}{$T N F-857 C>T$} \\
\hline GG & 220 & 219 & I & & \\
\hline GA & 45 & 58 & $1.32(0.85-2.04)$ & 0.41 & 0.19 \\
\hline AA & 3 & 4 & I.55(0.34-7.09) & & \\
\hline \multicolumn{6}{|l|}{ PTGSI V444I } \\
\hline GG & 265 & 280 & 1 & & \\
\hline $\mathrm{GA}$ & 5 & 3 & $0.52(0.12-2.22)$ & 0.36 & 0.36 \\
\hline AA & 0 & 0 & N.A. & & \\
\hline
\end{tabular}

I P-value for the codominant model, comparing heterogeneity among three genotypes

$2 \mathrm{P}$-value for the log-additive model, comparing the effect of each additional variant allele

draw any conclusion, and a much larger study is necessary to characterize better whether this SNP could play any role in the risk of CRC. All the other polymorphisms investigated showed clearly a lack of statistically significant association with CRC. The dominant or log-additive models did not change substantially the results (data not shown). No association was found when cases were classified according to cancer site (rectal, left colon or right colon, data not shown). The analyses for association based on interactions of these polymorphisms with dietary variables (alcohol, tobacco, coffee, vegetables, meat and meat products, fats, fruits, BMI, calories) did not elicit any statistical association (data not shown).
The lack of association can be due to three main reasons. First. In spite of the importance of the inflammation for the carcinogenic process of the colorectum, we, unfortunately, selected some of the inflammatory genes that do not have a role in this process. Second. It is also possible that, indeed, the genes have a role for $\mathrm{CRC}$, however the selected polymorphisms do not have biological effects for CRC. Third, it is possible that some of the SNPs have a small effect, which undergo undetected unless studied by analysing a much larger sample size. Although the present study does not seem to support a role for inflammatory polymorphisms, it should be stressed that our previous work did show a role for a polymorphism within the pro- 
Table 2: PCR primer and TaqMan ${ }^{\circledR}$ Probe Sequences

\begin{tabular}{|c|c|c|c|c|c|c|}
\hline Gene & Rs number & $\begin{array}{l}\text { Trivial } \\
\text { name }\end{array}$ & Primer Forward & Primer Reverse & VIC Probe & 6FAM Probe \\
\hline TLR4 & rs4986790 & Asp299Gly & $\begin{array}{l}\text { CCATTGAAGAATTC } \\
\text { CGATTAGCATA }\end{array}$ & $\begin{array}{l}\text { CACTCACCAGGG } \\
\text { AAAATGAAGAA }\end{array}$ & CCTCGATGATATTATT & CTCGATGGTATTATTG \\
\hline$C D / 4$ & rs2569190 & $-260 \mathrm{C}>\mathrm{T}$ & $\begin{array}{l}\text { GGAAATATTGCAAT } \\
\text { GAAGGATGTTT }\end{array}$ & $\begin{array}{l}\text { CTAGATGCCCTGC } \\
\text { AGAATCCTT }\end{array}$ & CTGTTACGGTCCCC & TGTTACGGCCCCC \\
\hline MCPI & rsl0246II & $-2518 A>G$ & $\begin{array}{l}\text { GGGAGGGCATCTT } \\
\text { TTCTTGAC }\end{array}$ & $\begin{array}{l}\text { GGTGAAGGGTAT } \\
\text { GAATCAGAAAAGA }\end{array}$ & ACAGCTATCACTTTC & AGACAGCTGTCACTTT \\
\hline$I L I 2 A$ & rs2243I38 & $+7506 \mathrm{~A}>\mathrm{T}$ & $\begin{array}{l}\text { AACCAGGAGTCCC } \\
\text { CGATCC }\end{array}$ & $\begin{array}{l}\text { GGCCCACTGCCC } \\
\text { AACAG }\end{array}$ & CCATGGAGTGGTACTG & AGGCCATGGTGTGGT \\
\hline$I L I 2 A$ & rs668998 & $+8707 A>G$ & $\begin{array}{l}\text { CCAATCTTTCTCCC } \\
\text { TGTAAATGTGTT }\end{array}$ & $\begin{array}{l}\text { TGAATGTCTAATA } \\
\text { GGGCAAGAATTTG }\end{array}$ & TGCATGACAAACAT & CTGCATGGCAAACA \\
\hline$I L I 2 A$ & rs2243I5I & $+9177 \mathrm{~A}>\mathrm{T}$ & $\begin{array}{l}\text { TTATTGCATGGTTA } \\
\text { GTTTTTCACTTTTT }\end{array}$ & $\begin{array}{l}\text { GGAGCATTGGAAT } \\
\text { GATTTGGTT }\end{array}$ & AGCATACTACACTACTTG & $\begin{array}{l}\text { AGCATACTACACAACT } \\
T\end{array}$ \\
\hline$I L I 2 A$ & rs2133310 & $+9508 \mathrm{G}>\mathrm{A}$ & $\begin{array}{l}\text { GGGACCTAATTAA } \\
\text { CTGTGTTATTGTGA }\end{array}$ & $\begin{array}{l}\text { AGCGGGTGTTCT } \\
\text { GATGTCTTG }\end{array}$ & AGTGCCAACACCTAG & TGCCAGCACCTAGT \\
\hline NOS2A & rs944722 & $+524 G>A$ & $\begin{array}{l}\text { CTCTGTTTCTCTGA } \\
\text { TCCСАСТTTCT }\end{array}$ & $\begin{array}{l}\text { GTGATATGAGATC } \\
\text { TCGCCACTACACT }\end{array}$ & TGGAGTCTCTGTCACC & $\begin{array}{l}\text { ATGGAGTTTCTGTCAC } \\
\text { C }\end{array}$ \\
\hline$T N F$ & rs1799724 & $-857 C>T$ & $\begin{array}{l}\text { GGTAGGAGAATGT } \\
\text { CCAGGGCTAT }\end{array}$ & $\begin{array}{l}\text { AGGTCCTGGAGG } \\
\text { CTCTTTCACT }\end{array}$ & CCCTGTCTTCGTTAAG & CCCTGTCTTCATTAAG \\
\hline PTGSI & rs5794 & V444I & $\begin{array}{l}\text { GCATGAAACCCTA } \\
\text { CACСTCСTT }\end{array}$ & $\begin{array}{l}\text { GGGACTGCATCC } \\
\text { AGGAAACA }\end{array}$ & AGGAGCTCGTAGGTGA & CAGGAGCTCATAGGT \\
\hline
\end{tabular}

moter of ILG and the polymorphism at codon 12 of PPARG [9]. However, IL6 and PPARG may be considered also as part of alternative pathways not directly linked to inflammation. IL6 is involved in the cross-talk between neutrophiles passed into the colon lumen and colocytes [9], whereas PPARG is involved in the resistance to insuline [9], thus, overall, our results seems to point towards other mechanisms, rather than stressing the role of inflammation for the CRC.

\section{Conclusion}

According to the results of our study, we conclude that the SNPs analysed do not have a strong impact on the risk of CRC.

\section{Methods}

Cases $(\mathrm{n}=377)$ were patients with a new diagnosis of CRC attending a University Hospital in Barcelona, Spain, between January 1996 and December 1998. All cases have had histological confirmation of their tumor diagnosis. Participation rate among cases was $72 \%$. Cases who did not participate in the study were similar to those included with respect to age, sex, tumor location, and extent.

Controls $(n=326)$ were randomly selected among patients admitted to the same hospital during the same period. To avoid selection bias, only incident cases were selected. Participation rate among controls was $69.4 \%$. All subjects had the same ethnicity (Caucasian). The ethical committee of the hospital approved the study and subjects gave informed consent at recruitment. Interviews of cases and controls were performed by trained personnel, using a structured test to determine demographic characteristics and potential risk factors for CRC. A more detailed report on study design has been previously published [9]. SNPs were selected based on previous publications from the literature. An extensive literature research was carried out with the aim to study the potential role of some inflammatory SNPs for CRC, once the information was available for other studies.

Genotyping was carried out with the 5 ' nuclease assay (TaqMan) by minor groove binder (MGB) probes fluorescently labelled with FAM or VIC and using the protocol recommended by the supplier (Applied Biosystems, Foster City, CA). To ensure quality control, DNA samples from cases and controls were randomly distributed on PCR plates, and all genotyping was conducted by personnel who were blinded to case - control status. Only genotype calls scored concordantly by two independent trained operators were retained. Finally, a random $8 \%$ of the samples were re-genotyped blindly. The probes and primers for the genotyping reactions are reported in Table 2. More details on the genotyping technique were reported previously [9].

Each polymorphism was tested in controls to ensure that it was in Hardy-Weinberg equilibrium. To test the hypothesis of association between genetic polymorphisms and CRC, multivariate methods based on logistic regression analyses were used. When cases were subdivided into groups, polytomous logistic regression was used, comparing each group of cases with the whole set of controls. Odds ratios (OR) and 95\% confidence intervals (CI) were 
calculated for each group compared to the homozygotes for the most common allele (set as having risk $=1$ ). For polymorphisms, homozygosity for the more frequent allele among controls was set as the reference class. Analyses were initially performed under a co-dominant model (three genotypes separated). A log-additive model to assess the effect of each additional rare allele and a codominant model were also explored to increase the statistical power. All analyses were adjusted for age and sex and $\mathrm{p}$ values were derived from likelihood ratio tests. More details concerning the statistical analyses were published previously [9].

The sample size of our study, for a rare allele frequency of $5 \%$, is enough to detect ORs greater than 2 with more than $90 \%$ power assuming a log-additive model. For allele frequencies of $15 \%$, the power to detect an OR of 1.5 is $82 \%$. For allele frequencies of $35 \%$ as observed for some SNPs in this study, the power to detect an OR of 1.3 is $66 \%$.

\section{Competing interests}

The author(s) declare that they have no competing interests.

\section{Authors' contributions}

SL, FB, LB, FC, VM contributed to the draft of the manuscript. FG, LGP, SL contributed to the wet lab. SL carried out the database and literature search for the selection of the candidate genes and polymorphisms. EG contributed to the statistical analysis. $\mathrm{MC}, \mathrm{SB}$ contributed in the recruitment and follow-up of patients. GC and VM designed the case-control study. FC run the laboratory. All authors read and approved the final manuscript.

\section{Acknowledgements}

The authors acknowledge the Bellvitge Colorectal Cancer Study Group

\section{References}

I. Coussens LM, Werb Z: Inflammation and cancer. Nature 2002, 420:860-867.

2. Phoa N, Epe B: Influence of nitric oxide on the generation and repair of oxidative DNA damage in mammalian cells. Carcinogenesis 2002, 23:469-475.

3. Jackson AL, Loeb LA: The contribution of endogenous sources of DNA damage to the multiple mutations in cancer. Mutat Res 200I, 477:7-2I.

4. Jackson JR, Seed MP, Kircher CH, Willoughby DA, Winkler JD: The codependence of angiogenesis and chronic inflammation. FASEB J 1997, I I:457-465.

5. Moore MA: Cytokine and chemokine networks influencing stem cell proliferation, differentiation, and marrow homing. J Cell Biochem Suppl 2002, 38:29-38.

6. Nakajima N, Kuwayama H, Ito Y, Iwasaki A, Arakawa Y: Helicobacter pylori, neutrophils, interleukins, and gastric epithelial proliferation. J Clin Gastroenterol I 997, 25(SuppI I):SI 98-202.

7. Eberhart CE, Coffey RJ, Radhika A, Giardiello FM, Ferrenbach S, DuBois RN: Up-regulation of cyclooxygenase 2 gene expression in human colorectal adenomas and adenocarcinomas. Gastroenterology 1994, 107: 1 183-1 188.

8. Itzkowitz SH, Yio X: Inflammation and cancer IV. Colorectal cancer in inflammatory bowel disease: the role of inflammation. Am J Physiol Gastrointest Liver Physiol 2004, 287:G7-17.
9. Landi S, Moreno V, Gioia-Patricola L, Guino E, Navarro M, de Oca J, Capella G, Canzian F, Bellvitge Colorectal Cancer Study Group: Association of common polymorphisms in inflammatory genes interleukin (IL)6, IL8, tumor necrosis factor alpha, NFKB I, and peroxisome proliferator-activated receptor gamma with colorectal cancer. Cancer Res 2003, 63:3560-3566.

10. Leung TF, Tang NL, Wong GW, Fok TF: CDI4 and toll-like receptors: potential contribution of genetic factors and mechanisms to inflammation and allergy. Curr Drug Targets Inflamm Allergy 2005, 4:169-175.

II. Schroder NW, Schumann RR: Single nucleotide polymorphisms of Toll-like receptors and susceptibility to infectious disease. Lancet Infect Dis 2005, 5:156-164.

12. Arroyo-Espliguero R, Avanzas P, Jeffery S, Kaski JC: CDI4 and tolllike receptor 4: a link between infection and acute coronary events? Heart 2004, 90:983-988.

13. Rovin BH, Lu L, Saxena R: A novel polymorphism in the MCP-I gene regulatory region that influences MCP-I expression. Biochem Biophys Res Commun I999, 259:344-348.

14. Becker C, Wirtz S, Neurath MF: Stepwise regulation of TH I responses in autoimmunity: IL-I 2-related cytokines and their receptors. Inflamm Bowel Dis 2005, I I:755-764.

15. Yilmaz V, Yentur SP, Saruhan-Direskeneli G: IL- $\mathbf{2} 2$ and IL- 10 polymorphisms and their effects on cytokine production. Cytokine 2005, 30: 188-194.

16. Albrecht EW, Stegeman CA, Heeringa P, Henning RH, van Goor H: Protective role of endothelial nitric oxide synthase. J Pathol 2003, 199:8-17.

17. Wallace JL, Miller MJ: Nitric oxide in mucosal defense: a little goes a long way. Gastroenterology 2000, I I 9:5 | 2-520.

18. Perner A, Rask-Madsen J: Review article: the potential role of nitric oxide in chronic inflammatory bowel disorders. Aliment Pharmacol Ther 1999, 13:135-144.

19. [http://www.ncbi.nlm.nih.gov/entrez/dispomim.cgi?id=191/60].

20. [http://www.ncbi.nlm.nih.gov/entrez/dispomim.cgi?id=153440].

21. Pfeffer K: Biological functions of tumor necrosis factor cytokines and their receptors. Cytokine Growth Factor Rev 2003, I4:185-19|.

22. Hampe J, Shaw SH, Saiz R, Leysens N, Lantermann A, Mascheretti S, Lynch NJ, MacPherson AJ, Bridger S, van Deventer S, Stokkers P, Morin P, Mirza MM, Forbes A, Lennard-Jones JE, Mathew CG, Curran ME, Schreiber S: Linkage of inflammatory bowel disease to human chromosome 6p. Am J Hum Genet 1999, 65:1647-1655.

23. Spahn TW, Herbst H, Rennert PD, Lugering N, Maaser C, Kraft M, Fontana A, Weiner HL, Domschke W, Kucharzik T: Induction of colitis in mice deficient of Peyer's patches and mesenteric lymph nodes is associated with increased disease severity and formation of colonic lymphoid patches. Am J Pathol 2002, 161:2273-2282.

24. Jones R, Adel-Alvarez LA, Alvarez OR, Broaddus R, Das S: Arachidonic acid and colorectal carcinogenesis. Mol Cell Biochem 2003, 253:I4I-I49.

25. Romano M, Claria J: Cyclooxygenase-2 and 5-lipoxygenase converging functions on cell proliferation and tumor angiogenesis: implications for cancer therapy. FASEB J 2003, 17:1986-1995.

26. IARC: Non steroidal anti-inflammatory drugs. IARC Handbooks of Cancer Prevention. Volume I. Lyon France: IARC Press; 1997.

27. Byrne MF, Murphy JF, Corcoran PA, Atherton JC, Sheehan KM, Cox $D$, Murray FE, Fitzgerald DJ: Helicobacter pylori induces cyclooxygenase- $I$ and cyclooxygenase- 2 expression in vascular endothelial cells. Scand J Gastroenterol 2003, 38: 1023-1030.

28. Cox DG, Pontes C, Guino E, Navarro M, Osorio A, Canzian F, Moreno V, Bellvitge Colorectal Cancer Study Group: Polymorphisms in prostaglandin synthase 2/cyclooxygenase 2 (PTGS2/COX2) and risk of colorectal cancer. Br J Cancer 2004, 91:339-343. 